\title{
EFFECT OF PRE-SOWING TREATMENTS ON SEED GERMINATION AND SEEDLING GROWTH OF CALLIANDRA HAEMATOCEPHALA HASSK. SHRUB
}

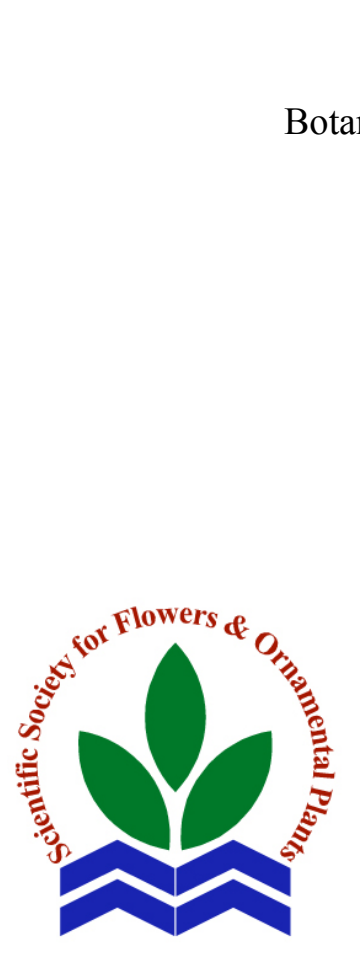

Scientific J. Flowers \& Ornamental Plants, 2(1):11-21 (2015).

Received:

$24 / 11 / 2014$

Revised by:

Prof. Dr. Eman M. Abou El-Ghait, Banha Univ.

Prof. Dr. M.M. Farahat, Agric. \& Biol. Res. Div., NRC.

S.M. Shahin; A.S. Tawila and Reem M. Said

Botanical Gardens Res. Dept., Hort. Res. Inst., ARC, Giza, Egypt.

\begin{abstract}
The present investigation was conducted at the nursery of Hort. Res. Inst., ARC, Giza, Egypt during 2013 and 2014 seasons to study the effect of different pre-sowing seed treatments, viz., untreated seeds (control), soaking in tap water for $24 \mathrm{~h}$ at room temperature, soaking in previously boiling water for $24 \mathrm{~h}$ at room temperature, boil/cold water dipping (thermal shock treatment), soaking in concentrated $\mathrm{H}_{2} \mathrm{SO}_{4}$ for either 2 or 4 min (chemical scarification) and abration testa with rough emery paper (mechanical scarification) on seed germination and seedling growth of Powder Puff (Calliandra haematocephala Hassk.) shrub.
\end{abstract}

The obtained results indicated that most of the used treatments improved germination $\%$ and velocity, mean germination rate, germination rate and vigour indices, seed viability and epicotyl length of germinated seeds, as well as seedling growth with various significant differences compared to control in the two seasons, except for thermal shock treatment which completely failed to induce germination. It was also noticed that seed viability markedly decreased as a result of mechanical scarification with emery paper to reach the least values at all. Content of total indoles and phenols in the untreated seeds was stable as they were not subjected to any treatment, but in treated seeds, it was increased where total indoles reached the maximum by soaking in either concentrated $\mathrm{H}_{2} \mathrm{SO}_{4}$ or boiling water, while these two treatments caused a nil increment in seed content of total phenols relative to control and other pre-sowing treatments. In addition, content of chlorophyll a, b, carotenoids and total soluble sugars in the leaves of seedlings raised from the treated seeds was greatly increased, especially by chemical and thermal scarification. Generally, the mastery in all previous measurements was for soaking in either concentrated $\mathrm{H}_{2} \mathrm{SO}_{4}$ for only $2 \mathrm{~min}$ or boiling water for $24 \mathrm{~h}$, as they recorded the utmost high means in the majority of measured traits in both seasons.

Hence, it is recommended to treat seeds of Calliandra haematocephala pre-sowing by soaking in either previously boiling water for $24 \mathrm{~h}$. or in concentrated $\mathrm{H}_{2} \mathrm{SO}_{4}$ for only 2 min. to obtain the best germination and seedling growth.

Key words: Calliandra haematocephala Hassk., germination, presowing, treatments, seedling growth. 


\section{INTRODUCTION}

Calliandra haematocephala Hassk., Powder Puff that belongs to Fam. Leguminosae (Fabaceaae) is an upright evergreen shrub, 2-4 $\mathrm{m}$ high, leaves bipinnate, leaflets numerous, bears attractive pink fluffy globose heads or inflorescences during the period from autumn to spring. Native to Bolivia, propagated by seeds and cuttings which placed in sand over bottom heat. It is one of the few mimosoid leguminous shrub planted primarily for their showy flowers and for shade due to their dispersed branches everywhere (Bailey, 1976 and Kong and Lum, 1996). It is grown as a hedge or shrub in the landscape for its powder puff-type flowers. Very attractive to bees and butterflies.

Seeds of most leguminous species are usually have hard-seed coat, solid endosperm or both, but they respond well to various presowing treatments, including thermal, mechanical and chemical scarifications. In this concern, Agba et al. (2005) mentioned that hot water treatment at $40-60{ }^{\circ} \mathrm{C}$ significantly enhanced germination of Mucuna flagellipes seeds compared to hot water treatment at higher temperatures $(80$ and $100{ }^{\circ} \mathrm{C}$ ). Soaking in water at room temperature for $36-48 \mathrm{~h}$ resulted in higher cumulative germination over planting of seeds without pre-sowing treatment. Kak et al. (2007) revealed that hot water at $80{ }^{\circ} \mathrm{C}$ for $5 \mathrm{~min}$ was found to be most effective in breaking hardseededness in Crotalaria laburnfolia, while germination declined sharply in $C$. retusa when seeds soaked in water at $70{ }^{\circ} \mathrm{C}$ for $15 \mathrm{~min}$. In C. pallida soaking seeds in hot water at $60{ }^{\circ} \mathrm{C}$ for 30 min enhanced germination. Likewise, Sharma et al. (2008) concluded that the best hot water treatment for seeds of Albizia lebbek and Peltophorum petrocarpum is 100 ${ }^{\circ} \mathrm{C}$ for 1 min (94 and 97\%, respectively), Lucaena leucocephala is $100{ }^{\circ} \mathrm{C}$ for $5 \mathrm{~min}$ (100\% germination) and for Albizia procera and Acacia auriculiformis is $100{ }^{\circ} \mathrm{C}$ for 10 min (94 and 98\% germination, respectively). On Acacia Melanoxylon, Burrows et al. (2009) stated that short exposure to boiling water (60 second or less) gave high germination percentages of seeds collected from 3 widely differing provenances in Australia. Similarly, were those results declared by Bahar (2007) on Acacia robusta, Singh and Dhillon (2007) on Acacia nilotica, Prosopis cineraria and Lucaena leucocephala, Sanyang et al. (2008) on Acacia senegal, Raghavendra et al. (2010) on Erythrina indica, Azad et al. (2010) on Albizia richardiana, Acacia catechu, and Melia azadirach, Azad et al. (2012) on Albizia procera and Junior et al. (2014) who observed that short-term exposure to a hot water treatment is sufficient for the formation of a water gap in Senna multijuga seeds, and only the lens acts in the imbibition process.

In some cases, both hot water soaking and sulfuric acid scarification gave better results. In this regard, Bahar (2011) reported that hot water soaking for $24 \mathrm{~h}$ or sulfuric acid for 15 min soaking enhanced germination of Acacia mangium seeds to more than $92 \%$. Similar observations were also recorded by Tadros et al. (2011) on Acacia farnesiana and Lucaena leucocephacla and Ghassali et al. (2012) on some species of Acacia.

Moreover, Singh et al. (2005) postulated that mechanical treatment enhanced germination of Pongamia glabra seeds up to $85 \%$ and the seeds treated with concentrated $\mathrm{HCl}$ for a minute showed 91.3\% germination, while those treated with hot water $\left(50{ }^{\circ} \mathrm{C}\right)$ exhibited highest germination (98\%). On the other hand, Kalia et al. (2005) found that mechanical scarification by rubbing seeds of Stylosanthes scabra with commercial thin sand paper for $5 \mathrm{~min}$ recorded highest germination percentage $(55.61 \%)$ followed by hot water treatment for $15 \mathrm{~min}(27.48 \%)$. On senna (Cassia angustifolia), Romamoorthy et al. (2005) noticed that commercial concentrated $\mathrm{H}_{2} \mathrm{SO}_{4}$ for 5 min minimized 
hard seed content to $3 \%$ compared to $87 \%$ in control and caused maximum seedling length $(13.7 \mathrm{~cm})$. This was followed by sand scarification for the same duration $(8 \%$ hard seeds and $13.9 \mathrm{~cm}$ seedling length). Hot water soaking for $15 \mathrm{~min}$ was less effective and furtherance to $30 \mathrm{~min}$ increased the percentage of dead seeds. On the same line, were those findings attained by Bhardwaj et al. (2006) on Albizia lebbek, Uniyal et al. (2007) on Dalbergia sissoo, Soliman and Abbas (2013) on Cassia fistula and Khan (2013) on Cassia auriculata and Cassia tora.

This work was done to detect the most practicable pre-sowing treatment to break the physical dormancy of Calliandra seeds.

\section{MATERIALS AND METHODS}

A study was undertaken at the nursery of Hort. Res. Inst., ARC, Giza, Egypt during the two consecutive seasons of 2013 and 2014 to overcome the physical dormancy of Powder Puff shrub seeds due to hardiness of testa.

Therefore, olive green seeds of Powder Puff (Calliandra haematocephala Hassk.) were collected from brown pods immediately after dehiscence and before dropping on the land during May for each season. The mean weight of 10 seeds was about $0.59-0.60 \mathrm{~g}$. The outer coats of the seeds were sterilized with $10 \%$ of Sodium Hydrochloride solution for 10 minutes, then rinsed several times with sterile distilled water and directly undergone on June, $1^{\text {st }}$ to the following pre-sowing treatments:

1- Untreated seeds, to be control.

2- Soaking in tap water for $24 \mathrm{~h}$ at ambient conditions.

3- Soaking in previously boiling water for 24 $\mathrm{h}$.

4- Dipping for 15 seconds in boiling water $\left(100{ }^{\circ} \mathrm{C}\right)$ and suddenly in cold one $\left(5^{\circ} \mathrm{C}\right)$, as a shock treatment.

5- Soaking in concentrated sulfuric acid $(98.5 \%)$ for either 2 or 4 min., as chemical scarification treatments.
6- Abration testa of the seeds at the two flattened sides with rough emery paper, as mechanical scarification treatment.

Immediately after treatment, the treated seeds and those of control were sown in 16$\mathrm{cm}$-diameter plastic pots filled with about $1.5 \mathrm{~kg}$ of sand and loam mixture at equal parts by volume. Some physical and chemical properties of the used sand and loam in the two seasons are shown in Table (1).

The pots were arranged under shade in a completely randomized design (Mead et al., 1993), with 3 replicates as each pot containing 10 seeds represents one replicate. Clearly visible epicotyl protrusion was used as a criterion for germination. All agricultural practices needed for care the seeds were done. Number of germinated seeds was counted daily and length of epicotyl $(\mathrm{cm})$ was measured after a week from emergence to calculate germination characteristics as follows:

1- Germination percentage (G. \%) from the following equation:

G. $\%=$ No. germinated seeds/total No. sown seeds $\times 100$

2- Germination velocity (G.V.) in days, which equal average number of days from sowing till emergence of the final epicotyl.

3- Mean germination rate (M.G.R.) in days = mean number of days till $50 \%$ germination (Odetola, 1987).

4- Germination rate index (G.R.I.), which calculated from Bartled equation indicated by Hartmann and Kester (1983). G.R.I. $=\mathrm{A}+(\mathrm{A}+\mathrm{B})+(\mathrm{A}+\mathrm{B}$ $+\mathrm{C})+\ldots$ N $(\mathrm{A}+\mathrm{B}+\mathrm{C} \ldots .$.$) .$

- Where: A, B, C, .... etc. are number of germinated seeds counted at different times, and $\mathrm{N}$ is number of times at which the germinated seeds were counted.

5- Vigour index (V.I.) $=$ G. $\% \times$ mean length of epicotyl (Selvaraju and Selvaraj, 1994). 
Table 1. The physical and chemical analysis of the used sand and loam during 2013 and 2014 seasons.

\begin{tabular}{|c|c|c|c|c|c|c|c|c|c|c|c|c|c|c|c|}
\hline \multirow{2}{*}{$\begin{array}{c}\text { Soil } \\
\text { texture }\end{array}$} & \multirow[b]{2}{*}{ Seasons } & \multicolumn{4}{|c|}{ Particle size distribution (\%) } & \multirow[b]{2}{*}{ S.P. } & \multirow{2}{*}{$\begin{array}{c}\text { E.C. } \\
(\mathrm{dS} / \mathrm{m})\end{array}$} & \multirow{2}{*}{ pH } & \multicolumn{4}{|c|}{ Cations (meq/l) } & \multicolumn{3}{|c|}{ Anions (meq/l) } \\
\hline & & $\begin{array}{c}\text { Coarse } \\
\text { sand }\end{array}$ & $\begin{array}{l}\text { Fine } \\
\text { sand }\end{array}$ & Silt & Clay & & & & $\mathrm{Ca}^{++}$ & $\mathrm{Mg}^{++}$ & $\mathrm{Na}^{+}$ & $\mathbf{K}^{+}$ & $\mathrm{HCO}_{3}^{-}$ & $\mathrm{Cl}^{-}$ & $\mathrm{SO}_{4}^{--}$ \\
\hline \multirow{2}{*}{ Sand } & 2013 & 89.03 & 2.05 & 0.40 & 8.52 & 23.00 & 3.72 & 7.92 & 7.50 & 1.63 & 33.60 & 0.50 & 3.20 & 22.00 & 18.03 \\
\hline & 2014 & 90.10 & 1.95 & 0.50 & 7.45 & 22.86 & 3.74 & 7.80 & 19.42 & 8.33 & 7.20 & 0.75 & 1.60 & 7.00 & 27.10 \\
\hline \multirow{2}{*}{ Loam } & 2013 & 10.18 & 46.17 & 19.53 & 24.12 & 35.00 & 3.38 & 8.09 & 17.50 & 9.42 & 20.00 & 0.79 & 3.80 & 10.00 & 33.91 \\
\hline & 2014 & 10.30 & 46.54 & 18.88 & 24.28 & 33.00 & 3.51 & 8.16 & 18.00 & 8.95 & 20.50 & 0.85 & 3.65 & 10.20 & 34.45 \\
\hline
\end{tabular}

6- Seed viability $(\mathrm{SV})$ = number of survived seedlings in each treatment after excluding the deteriorated and dead ones (Odetola, 1987).

At the end of experiment (on $30^{\text {th }}$ of June for both seasons), the following data were recorded on the resulted seedlings from the different treatments: seedling length $(\mathrm{cm})$, number of leaves/seedling, root length $(\mathrm{cm})$, number of root branches/main root, as well as top growth and roots fresh and dry weights $(\mathrm{g})$.

In fresh seed samples taken only in the second season, total indoles (A.O.A.C., 1990) and total phenols (William et al., 1965) were measured before and after treatment, while in fresh leaf ones, photosynthetic pigments (chlorophyll a, b and carotenoids, $\mathrm{mg} / \mathrm{g}$ f.w.) and the percentage of total soluble sugars were measured according to the methods explained by Saric et al. (1967) and Dubois et al. (1956), respectively.

Data were then tabulated and subjected to analysis of variance using SAS Institute program (1994), and Duncan's Multiple Range Test (Duncan, 1955), to explore the significance level among the means of various treatments.

\section{RESULTS AND DISCUSSION}

\section{Effect of pre-sowing treatments on:}

\section{Germination traits and epicotyl length:}

Data in Table (2) clear that germination $\%$ reached the maximum by soaking in both boiling water for $24 \mathrm{~h}$ and concentrated $\mathrm{H}_{2} \mathrm{SO}_{4}$ for either 2 or 4 minutes, as these treatments gave $100 \%$ germination in the two seasons, and followed by soaking in tap water for $24 \mathrm{~h}(75 \%$ germination in both seasons). The least improvement in germination \% was attained by mechanical scarification with emery paper that increased such parameter to 62.50 and $55.78 \%$ against 50.00 and $40.36 \%$ for control in the first and second seasons, respectively. On the other side, seeds treated with thermal shock treatment failed to germinate giving 00.00 germination percent in the two seasons. This may be ascribed to the harmful effect of shock treatment on embryo vitality.

The least number of days to either final germination $(100 \%)$ or half one $(50 \%)$ was found due to chemical scarification treatment by soaking in concentrated $\mathrm{H}_{2} \mathrm{SO}_{4}$ for 2 min only, which was followed by soaking in such acid for $4 \mathrm{~min}$, and then by soaking in previously boiling water for $24 \mathrm{~h}$. However, the highest means of germination rate index, as a real indicator for germination accelerating was also achieved by soaking in concentrated $\mathrm{H}_{2} \mathrm{SO}_{4}$ treatment for $2 \mathrm{~min}$, which significantly raised this parameter to 0.88 and 1.33 in the $1^{\text {st }}$ and $2^{\text {nd }}$ seasons, respectively, and also by soaking in boiling water for $24 \mathrm{~h}$ treatment that increased value of such index to 0.75 in the $1^{\text {st }}$ season and to 0.86 in the $2^{\text {nd }}$ one. Furthermore, the highest means of vigour index, seed viability and epicotyl length $(\mathrm{cm})$ were also attributed to soaking in previously boiling water for $24 \mathrm{~h}$ treatment which registered the highest records in both seasons, followed by soaking in concentrated $\mathrm{H}_{2} \mathrm{SO}_{4}$ for $2 \mathrm{~min}$, and then soaking in the same acid for $4 \mathrm{~min}$. Seed viability recorded by mechanical scarification treatment was reduced to 1.00 
Table 2. Effect of pre-germination treatments on germination traits and epicotyl length of Calliandra haematocephala Hassk. shrub seeds during 2013 and 2014 seasons.

\begin{tabular}{|c|c|c|c|c|c|c|c|}
\hline Treatments & 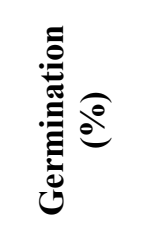 & 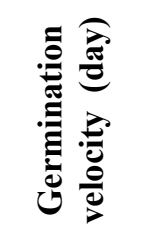 & 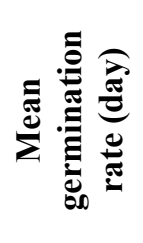 & 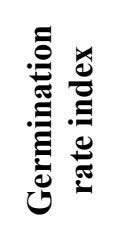 & 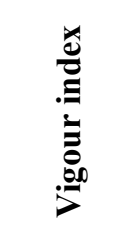 & 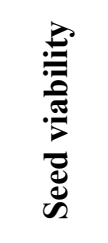 & 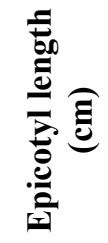 \\
\hline & \multicolumn{7}{|c|}{ First season: 2013} \\
\hline Control & $50.00 \mathrm{~d}$ & $30.00 \mathrm{a}$ & $30.00 \mathrm{a}$ & $0.75 \mathrm{ab}$ & $128.00 \mathrm{c}$ & $2.00 \mathrm{c}$ & $2.56 \mathrm{c}$ \\
\hline Soaking in tap water for $24 \mathrm{~h}$ & $75.00 \mathrm{~b}$ & $30.00 \mathrm{a}$ & $15.50 \mathrm{~b}$ & $0.67 b$ & $215.25 b$ & $3.00 \mathrm{~b}$ & $2.87 \mathrm{bc}$ \\
\hline Soaking in boiling water for $24 \mathrm{~h}$ & $100.00 \mathrm{a}$ & $9.50 \mathrm{~cd}$ & $4.00 \mathrm{c}$ & $0.75 \mathrm{ab}$ & $483.00 \mathrm{a}$ & $4.00 \mathrm{a}$ & $4.83 \mathrm{a}$ \\
\hline Boiling/cold water dipping & - & - & - & - & - & - & - \\
\hline Soaking in concn. $\mathrm{H}_{2} \mathrm{SO}_{4}$ for $2 \mathrm{~min}$ & $100.00 \mathrm{a}$ & $4.50 \mathrm{c}$ & $2.00 \mathrm{c}$ & $0.88 \mathrm{a}$ & $451.00 \mathrm{a}$ & $4.00 \mathrm{a}$ & $4.51 \mathrm{a}$ \\
\hline Soaking in concn. $\mathrm{H}_{2} \mathrm{SO}_{4}$ for $4 \mathrm{~min}$ & $100.00 \mathrm{a}$ & $7.33 \mathrm{c}$ & $2.00 \mathrm{c}$ & $0.75 \mathrm{ab}$ & $426.00 \mathrm{a}$ & $4.00 \mathrm{a}$ & $4.26 \mathrm{a}$ \\
\hline \multirow[t]{2}{*}{ Scarification with emery paper } & $62.50 \mathrm{c}$ & $15.00 \mathrm{~b}$ & $15.00 \mathrm{~b}$ & $0.75 \mathrm{ab}$ & $208.13 b$ & $1.00 \mathrm{~d}$ & $3.33 \mathrm{a}$ \\
\hline & \multicolumn{7}{|c|}{ Second season: 2014} \\
\hline Control & $40.36 \mathrm{~d}$ & $30.50 \mathrm{a}$ & - & $0.67 \mathrm{bc}$ & $132.38 \mathrm{~d}$ & $3.00 \mathrm{c}$ & $3.28 \mathrm{c}$ \\
\hline Soaking in tap water for $24 \mathrm{~h}$ & $75.00 \mathrm{~b}$ & $27.00 \mathrm{a}$ & $13.96 \mathrm{a}$ & $0.63 \mathrm{c}$ & $278.15 \mathrm{c}$ & $4.33 b$ & $3.71 b c$ \\
\hline Soaking in boiling water for $24 \mathrm{~h}$ & $100.00 \mathrm{a}$ & $10.33 \mathrm{~cd}$ & $4.35 \mathrm{~b}$ & $0.86 b$ & $630.00 \mathrm{a}$ & $5.76 \mathrm{a}$ & $6.30 \mathrm{a}$ \\
\hline Boiling/cold water dipping & - & - & - & - & - & - & - \\
\hline Soaking in conc. $\mathrm{H}_{2} \mathrm{SO}_{4}$ for $2 \mathrm{~min}$ & $100.00 \mathrm{a}$ & $5.76 \mathrm{c}$ & $2.60 \mathrm{~b}$ & $1.33 \mathrm{a}$ & $586.00 \mathrm{a}$ & $5.00 \mathrm{a}$ & $5.86 \mathrm{a}$ \\
\hline Soaking in conc. $\mathrm{H}_{2} \mathrm{SO}_{4}$ for $4 \mathrm{~min}$ & $100.00 \mathrm{a}$ & $9.10 \mathrm{c}$ & $2.76 b$ & $0.80 \mathrm{~b}$ & $547.00 \mathrm{a}$ & $5.00 \mathrm{a}$ & $5.47 \mathrm{ab}$ \\
\hline Scarification with emery paper & $55.78 \mathrm{c}$ & $17.67 \mathrm{~b}$ & $16.97 \mathrm{a}$ & $0.76 \mathrm{~b}$ & $238.18 \mathrm{c}$ & $2.33 \mathrm{c}$ & $4.27 b$ \\
\hline
\end{tabular}

Means within a column having the same letters are not significantly different according to Duncan's Multiple Range Test (DMRT) at $5 \%$ level.

and 2.33 against 2.00 and 3.00 for control in the first and second seasons, consecutively due to death some of the produced seedlings under such treatment.

It seems from the previous gains that both boiling water and concentrated sulfuric acid improved the most germination characters because of their ability on softening the hard palisade layer that present in seed coat in most legumes and casually connected with their higher degree of impermeability (Khan, 2013). In this connection, Burrows et al. (2009) affirmed that structure of the lens in the coat of Acacia melanoxylon seeds was markedly altered after a 10-second exposure to boiling water. A wide diversily of altered lens structure was found from a circular hole between the macrosclereids, to a short fissure where the macrosclereids did not separate to their basis. Besides, Wen et al.
(2009) demonstrated that seeds of Vigna oblongifolia first cracked in the hilum when pretreated with sulfuric acid, but they cracked in both the hilum and extrahilar regions when pretreated with hot water. However, in Sesbania sesban seeds, a crack formed only in the lens following either acid scarification or hot water treatments, and the seeds imbibed water only through the lens. This means that the primary site of water entry into seeds following physical dormancy break can vary with species and treatments. These results are in accordance with those detected by Singh et al. (2005) on Pongamia glabra, Bhardwaj et al. (2006) on Albizia lebbek, Sharma et al. (2008) on Albizia lebbek, A. procera, Peltophorum petrocarpum, Lucacena leucocephala and Acacia auriculiformis, Azad et al. (2010) on Albizia richardiana and Lagerstroemia speciosa, Tadros et al. (2011) on Acacia 
farnesiana, Soliman and Abbas (2013) on Cassia fistula and Junior et al. (2014) on Senna multijuga.

\section{Seedling growth traits:}

As shown in Tables (3 and 4), it is evident that the best seedling growth was achieved by soaking seeds in boiling water for $24 \mathrm{~h}$ treatment, as this treatment produced the longest seedling and root lengths $(\mathrm{cm})$, the highest number of leaves and root branches/seedling, as well as the heaviest fresh and dry weights $(\mathrm{g})$ of top growth and roots with significant differences when compared to control and other treatments in most cases of both seasons. Soaking in concentrated $\mathrm{H}_{2} \mathrm{SO}_{4}$ for only 2 min gave better growth means closely near to those attained by boiling water treatment with few exceptions in the two seasons, while elongating duration of soaking in the acid did not cause any additional increment in growth of the resulted seedlings, but slightly reduced means of the most growth characters comparing with soaking for $2 \mathrm{~min}$. The least improvement in growth, however was established by mechanical scarification with emery paper, and then by soaking in tap water for $24 \mathrm{~h}$.

Improvement of vegetative and root growth of seedlings due to soaking in either boiling water or concentrated sulfuric acid may be attributed to that these two treatments softened the hard seed coats and altered lens structure, and that permites the seeds to absorb more water and gasses necessary for hydrolysis of the complex food reserves to absorbable forms. Moreover, early germination under these two treatments saving more time for the produced seedlings to grow more and more, whereas seeds under other treatments are still dormant. Similar observations were also explored by Kalia et al. (2005) on Stylosanthes scabra, Kak et al. (2007) on Crotalaria laburnifolia and $C$. pallida, Sanyang et al. (2008) on Acacia Senegal, Dhanda et al. (2011) on Albizia lebbek, Acacia catechu, and Melia azadirach and Khan (2013) on Cassia auriculata and Cassia tora.

\section{Chemical composition:}

From data averaged in Table (5), it can be say that content of either total indoles or total phenols (ppm) in the seeds before treatments was closely near together, as it ranged between $0.118-0.121$ and 0.0019-0.0021 ppm for these two constituents, respectively. Content of these two components was not change in the untreated seeds after-treatment as they received no treatment. The opposite was the right regarding the treated seeds as their content of such constituents was markedly increased, especially by soaking in concentrated $\mathrm{H}_{2} \mathrm{SO}_{4}$ for $2 \mathrm{~min}$ treatment, which increased total indoles to $3.283 \mathrm{ppm}$, while prolonging soaking time to $4 \mathrm{~min}$ and soaking in boiling water for $24 \mathrm{~h}$ raised it to the only 2.717 and 1.838 ppm, consecutively. On the other hand, increment in total phenols content due to the aforementioned treatments was nil, as it ranged between 0.0020-0.0023 ppm against $0.0020 \mathrm{ppm}$ in control seeds. So, the best enhancing for germination velocity was found due to these 3 treatments which induced germination within about 5-10 days. The thermal shock treatment increased total indoles content to 1.8-fold over control, but raised total phenols one to 12-fold over control, so seeds subjected to this treatment failed to germinate. This result may indicate the inhibitory effect of phenols which modify the activity of IAA-oxidase and might therefore be acting on plant activities through changes endogenous auxins activity (Kenneth, 1979).

As for leaf content of chlorophyll a, b and carotenoids (mg/g f.w.) and total soluble sugars (\%), data in Table (6) show that a pronounced increment in their content was observed due to the different pre-sowing treatments used in this study, with the prevalence of soaking in both concentrated $\mathrm{H}_{2} \mathrm{SO}_{4}$ and boiling water treatments which elevated content of such components to the highest means contrary to control and other treatments. On the same line, were those results elicited by Agba et al. (2005) Mucuna flagellipes, Burrows et al. (2009) on Acacia Melanoxylon Azad et al. (2012) on Albizia 
Table 3. Effect of pre-germination treatments on growth traits of Calliandra haematocephala Hassk. seedlings during 2013 and 2014 seasons.

\begin{tabular}{|c|c|c|c|c|c|c|c|c|}
\hline \multirow[t]{2}{*}{ Treatments } & \multicolumn{2}{|c|}{$\begin{array}{l}\text { Seedling length } \\
\qquad(\mathrm{cm})\end{array}$} & \multicolumn{2}{|c|}{$\begin{array}{l}\text { No. leaves per } \\
\text { seedling }\end{array}$} & \multicolumn{2}{|c|}{$\begin{array}{l}\text { Root length } \\
(\mathrm{cm})\end{array}$} & \multicolumn{2}{|c|}{$\begin{array}{l}\text { No. root branches } \\
\text { per main root }\end{array}$} \\
\hline & 2013 & 2014 & 2013 & 2014 & 2013 & 2014 & 2013 & 2014 \\
\hline Control & $5.70 \mathrm{c}$ & $6.48 \mathrm{c}$ & $2.00 \mathrm{~b}$ & $2.00 \mathrm{c}$ & $5.30 \mathrm{~d}$ & $6.34 d$ & $1.40 \mathrm{c}$ & $1.50 \mathrm{c}$ \\
\hline Soaking in tap water for $24 \mathrm{~h}$ & $6.56 \mathrm{c}$ & $7.80 \mathrm{c}$ & $2.67 \mathrm{~b}$ & $3.00 \mathrm{~b}$ & $8.23 \mathrm{c}$ & $9.51 \mathrm{c}$ & $2.80 \mathrm{bc}$ & $2.99 \mathrm{bc}$ \\
\hline Soaking in boiling water for $24 \mathrm{~h}$ & $13.50 \mathrm{a}$ & $16.21 \mathrm{a}$ & $4.00 \mathrm{a}$ & $5.00 \mathrm{a}$ & $15.60 \mathrm{a}$ & $18.03 \mathrm{a}$ & $5.43 \mathrm{a}$ & $6.00 \mathrm{a}$ \\
\hline Boiling/cold water dipping & - & - & - & - & - & - & - & - \\
\hline Soaking in conc. $\mathrm{H}_{2} \mathrm{SO}_{4}$ for $2 \mathrm{~min}$ & $11.33 \mathrm{ab}$ & $13.56 \mathrm{ab}$ & $4.00 \mathrm{a}$ & $4.67 \mathrm{a}$ & $10.46 b$ & $1250 \mathrm{~b}$ & $3.50 \mathrm{~b}$ & $3.76 b$ \\
\hline Soaking in conc. $\mathrm{H}_{2} \mathrm{SO}_{4}$ for $4 \mathrm{~min}$ & $11.20 \mathrm{ab}$ & $13.40 \mathrm{ab}$ & $3.33 \mathrm{a}$ & $3.50 \mathrm{~b}$ & $9.50 \mathrm{bc}$ & $11.50 \mathrm{bc}$ & $3.10 \mathrm{~b}$ & $3.33 b$ \\
\hline Scarification with emery paper & $9.33 b$ & $11.00 \mathrm{~b}$ & $3.00 \mathrm{ab}$ & $3.26 \mathrm{~b}$ & $9.00 \mathrm{bc}$ & $10.75 \mathrm{bc}$ & $3.00 \mathrm{~b}$ & $3.21 \mathrm{~b}$ \\
\hline
\end{tabular}

Means within a column having the same letters are not significantly different according to Duncan's Multiple Range Test (DMRT) at 5\% level.

Table 4. Effect of pre-germination treatments on top growth and roots fresh and dry weights of Calliandra haematocephala Hassk. seedlings during 2013 and 2014 seasons.

\begin{tabular}{lccccccccc}
\hline \multicolumn{1}{c}{ Treatments } & \multicolumn{3}{c}{ Fresh weight (g) } & \multicolumn{4}{c}{ Dry weight (g) } \\
\cline { 2 - 10 } & \multicolumn{2}{c}{ Top growth } & \multicolumn{2}{c}{ Roots } & \multicolumn{2}{c}{ Top growth } & \multicolumn{2}{c}{ Roots } \\
& $\mathbf{2 0 1 3}$ & $\mathbf{2 0 1 4}$ & $\mathbf{2 0 1 3}$ & $\mathbf{2 0 1 4}$ & $\mathbf{2 0 1 3}$ & $\mathbf{2 0 1 4}$ & $\mathbf{2 0 1 3}$ & $\mathbf{2 0 1 4}$ \\
\hline Control & $0.17 \mathrm{c}$ & $0.19 \mathrm{c}$ & $0.04 \mathrm{c}$ & $0.05 \mathrm{c}$ & $0.054 \mathrm{c}$ & $0.061 \mathrm{~d}$ & $0.018 \mathrm{e}$ & $0.023 \mathrm{~d}$ \\
Soaking in tap water for $\mathbf{2 4} \mathbf{~ h}$ & $0.22 \mathrm{~b}$ & $0.25 \mathrm{~b}$ & $0.07 \mathrm{bc}$ & $0.08 \mathrm{cb}$ & $0.071 \mathrm{~b}$ & $0.078 \mathrm{c}$ & $0.034 \mathrm{~d}$ & $0.037 \mathrm{~cd}$ \\
Soaking in boiling water for $\mathbf{2 4} \mathbf{h}$ & $0.41 \mathrm{a}$ & $0.47 \mathrm{a}$ & $0.15 \mathrm{a}$ & $0.17 \mathrm{a}$ & $0.136 \mathrm{a}$ & $0.145 \mathrm{a}$ & $0.073 \mathrm{a}$ & $0.078 \mathrm{a}$ \\
Boiling/cold water dipping & - & - & - & - & - & - & - & - \\
Soaking in conc. $\mathbf{H}_{\mathbf{2}} \mathbf{S O}_{\mathbf{4}}$ for $\mathbf{2} \mathbf{~ m i n}$ & $0.32 \mathrm{a}$ & $0.35 \mathrm{ab}$ & $0.14 \mathrm{a}$ & $0.15 \mathrm{a}$ & $0.103 \mathrm{ab}$ & $0.110 \mathrm{ab}$ & $0.061 \mathrm{~b}$ & $0.063 \mathrm{~b}$ \\
Soaking in conc. $\mathbf{H}_{\mathbf{2}} \mathbf{S O}_{\mathbf{4}}$ for $\mathbf{4} \mathbf{~ m i n}$ & $0.26 \mathrm{ab}$ & $0.29 \mathrm{~b}$ & $0.10 \mathrm{~b}$ & $0.11 \mathrm{~b}$ & $0.081 \mathrm{~b}$ & $0.093 \mathrm{~b}$ & $0.045 \mathrm{c}$ & $0.050 \mathrm{c}$ \\
Scarification with emery paper & $0.20 \mathrm{~b}$ & $0.23 \mathrm{bc}$ & $0.09 \mathrm{~b}$ & $0.11 \mathrm{~b}$ & $0.062 \mathrm{c}$ & $0.074 \mathrm{c}$ & $0.039 \mathrm{~cd}$ & $0.046 \mathrm{c}$ \\
\hline
\end{tabular}

Means within a column having the same letters are not significantly different according to Duncan's Multiple Range Test (DMRT) at 5\% level.

Table 5. Effect of pre-germination treatments on total indoles and phenols in the seeds of Calliandra haematocephala Hassk. before and after treatment during 2014 season.

\begin{tabular}{lcccc}
\hline \multicolumn{1}{c}{ Treatments } & \multicolumn{2}{c}{ Total indoles (ppm) } & \multicolumn{2}{c}{ Total phenols (ppm) } \\
& Before treat. & After treat. & Before treat. & After treat. \\
\hline Control & 0.121 & 0.121 & 0.0020 & 0.0020 \\
Soaking in tap water for $\mathbf{2 4} \mathbf{~ h}$ & 0.120 & 0.169 & 0.0021 & 0.0034 \\
Soaking in boiling water for $\mathbf{2 4} \mathbf{~ h}$ & 0.120 & 1.838 & 0.0021 & 0.0023 \\
Boiling/cold water dipping & 0.121 & 0.215 & 0.0021 & 0.0233 \\
Soaking in conc. $\mathbf{H}_{2} \mathbf{S O}_{\mathbf{4}}$ for $\mathbf{2}$ min & 0.118 & 3.283 & 0.0020 & 0.0020 \\
Soaking in conc. $\mathbf{H}_{\mathbf{2}} \mathrm{SO}_{\mathbf{4}}$ for $\mathbf{4}$ min & 0.121 & 2.717 & 0.0019 & 0.0021 \\
Scarification with emery paper & 0.120 & 0.320 & 0.0021 & 0.0029 \\
\hline
\end{tabular}


Table 6. Effect of pre-germination treatments on pigments and total soluble sugars content in the leaves of Calliandra haematocephala Hassk. seedlings during 2014 season.

\begin{tabular}{|c|c|c|c|c|}
\hline \multirow{2}{*}{ Treatments } & \multicolumn{3}{|c|}{ Pigments Content (mg/g f.w.) } & \multirow{2}{*}{$\begin{array}{c}\text { Total soluble } \\
\text { sugars (\%) } \\
\text { After treat. }\end{array}$} \\
\hline & Chlorophyll & rophyll (b) & Carotenoids & \\
\hline Control & 0.332 & 0.141 & 0.081 & 1.074 \\
\hline Soaking in tap water for $24 \mathrm{~h}$ & 0.499 & 0.218 & 0.175 & 1.208 \\
\hline Soaking in boiling water for $24 \mathrm{~h}$ & 1.150 & 0.401 & 0.360 & 1.252 \\
\hline Boiling/cold water dipping & - & - & - & - \\
\hline Soaking in conc. $\mathrm{H}_{2} \mathrm{SO}_{4}$ for $2 \mathrm{~min}$ & 1.784 & 0.631 & 0.433 & 3.088 \\
\hline Soaking in conc. $\mathrm{H}_{2} \mathrm{SO}_{4}$ for $4 \mathrm{~min}$ & 1.376 & 0.387 & 0.400 & 2.327 \\
\hline Scarification with emery paper & 0.597 & 0.246 & 0.193 & 1.200 \\
\hline
\end{tabular}

procera and Khan (2013) on Cassia auriculata and Cassia tora.

From the aforestated results, it can be concluded that soaking in either previously boiling water for $24 \mathrm{~h}$ or concentrated sulfuric acid $(98.5 \%)$ for only 2 min are considered the most practicable pre-sowing treatments for germination of Calliandra haematocephala Hassk. seeds and for the best growth of the produced seedlings (Fig. $1)$.

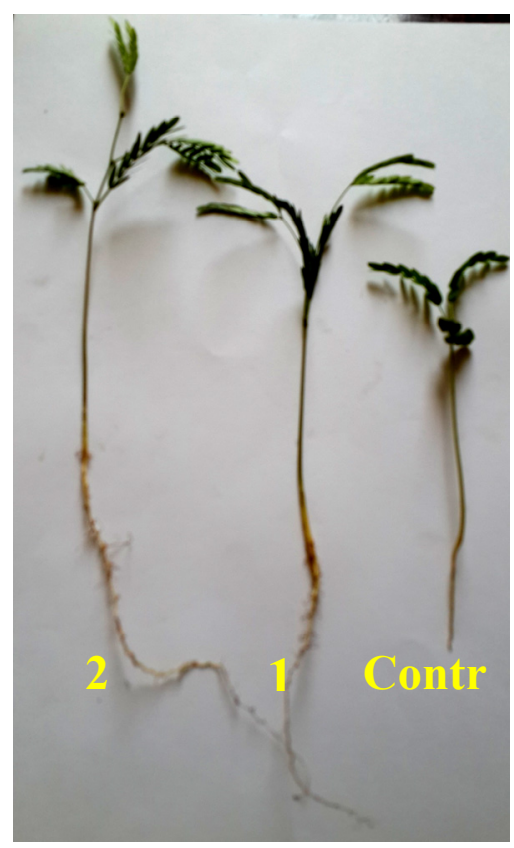

Fig. 1. Effect of soaking in boiling water (1) and concentrated $\mathrm{H}_{2} \mathrm{SO}_{4}$ for 2 min (2) on seedling growth compared to control.

\section{REFERENCES}

Agba, O.A.; Asiegbu, J.E. and Omaliko, C.P.E. (2005). Effect of length of soaking in water at room temperature and hot water treatment on the germination of Mucuna flagellipes, Vogel ex Hook seeds. Global J. Agric. Sci., 4(1):15-18.

A.O.A.C. (1990). Association of Official Agricultural Chemists "Official Methods of Analysis of the association of Official Agricultural Chemists". $15^{\text {th }}$ Ed., Arlington, Virginia 22201: 877-878.

Azad, M.S.; Biswas, R.K. and Abdul Matin, M. (2012). Seed germination of Albizia procera (Roxb) Benth. In Bangladesh: a basis for seed source variation and presowing treatment effect. Forestry Studies in China, 14(2):124-130.

Azad, M.S.; Paul, N.K. and Abdul Matin, M. (2010). Do pre-sowing treatments affect seed germination in Albizia richardiana and Lagerstroemia speciosa?. Frontiers of Agriculture in China, 4(2):181-184.

Bahar, N. (2007). Pod and seed characteristics and effect of pretreatment on seed germination of Acacia robusta Burchell. Indian J. Forestry, 30(3):333336.

Bahar, N. (2011). Evaluation of pretreatment techniques to enhance seed germination of Acacia mangium Wild. Annals of Forestry, 19(2):221-226. 
Bailey, L.H. (1976). Hortus Third, Macmillan Publishing Co., Inc., 866 Third Avenue, New York, N. Y. 10022. Printed in USA, pp. 1290.

Bhardwaj, N.R.; Chandel, R.S. and Pathania, N. (2006). Effect of pre-sowing treatments on germination behavior and seedling vigour index of Albizia lebbek seeds. Proc. of the IUFRO-ISTS-UHF Inter. Conf. of World Prespective on Short Rotation Forestry For Industrial and Rural Development, Nauni, Solan, India, 7-13 Sept., 276-278.

Burrows, G.E.; Virgona, J.M. and Heady, R.D. (2009). Effect of boiling water, seed coat structure and provenance on the germination of Acacia melanoxylon seeds. Australian J. Botany, 57(2):139147.

Dhanda, S.K.; Verma, R.C. and Panwar, R.D. (2011). Seed and seedling quality of some multipurpose tree species of arid and semi-arid regions. Environment and Ecology, 29 (1 A): 442-447.

Dubois, M.; Smith, F.; Illes, K.A.; Hamilton, J.K. and Rebers, P.A. (1956). Colorimetric method for determination of sugars and related substances. Ann. Chem., 28(3):350-356.

Duncan, D.B. (1955). Multiple range and multiple F. Tests. Biometrics,11: 1- 24.

Ghassali, F.; Salkini, A.K.; Petersen, S.L.; Niane, A.A. and Lauhaichi, M. (2012). Germination dynamics of Acacia species under different seed treatments. Range Management and Agroforestry, 33(1):3742.

Hartmann, H.T. and Kester, D.E. (1983). Plant Propagation: Principles and Practices. Prentice-Hall Inc., Inglewood Cliffs, N. J., 662pp.

Junior, R.A.G.; Faria, J.M.R.; Vaz, T.A.A.; Nakamura, A.T. and Jose, A.C. (2014). Physical dormancy in Senna multijuga seeds: the role of seed structure in waste water uptake. Seed Science research, 24(2):147-157.
Kak, A.; Devi, L.C.; Gupta, V. and Singh, N. (2007). Response of seed treatments on seed germination in wild Crotalaria species. Acta Hort., 752:261-265.

Kalia, V.; Chandel, K. and Kumar, P. (2005). Effect of scarification treatments on germination of shrubby stylo (Stylosanthes scabra) seeds. Seed Research, 33(1):119.

Kenneth, V.T. (1979). Physiology of Plant Growth and Development. B. Willkins TaTa, McGraw-Hill Publishing Co. Ltd., New Delhi.

Khan, M.R. (2013). The effects of pretreatments on seed germination of Cassia auriculata L. and Cassia tora L. Advances in Plant Sciences, 26(1):253256.

Kong, L. S. and Lum, S. (1996). A Guid to Common Horticultural Shrub. $1^{\text {st }}$ Ed., Singapore Science Center, Singapore, 609081, p. 71.

Mead, R.; Curnow, R.N. and Harted, A.M. (1993). Statistical Methods in Agriculture and Experimental Biology. $2^{\text {nd }}$ Ed., Chapman \& Hall Ltd., London, 335 pp.

Odetola, J.A. (1987). Studies on seed dormancy, viability and germination in ornamental palms. Principes, 31(1):2430 .

Raghavendra, S.M.; Shankanur, M.; Venkatesh, L. and Nagarajaiah, C. (2010). Duration of hot water treatment on seed germination of Erythrina indica L. Environment and Ecology, 28(3 B):2123-2124.

Ramamoorthy, K.; Rajendran, C. and Sivasubramanian, S. (2005). Seed treatment for alleviation of hardseededness in senna (Cassia angustifolia L.). Advances in Plant Sciences, 18(1):429-430.

Sanyang, S.E.; Kabura, B.H. and Wenchi, H. (2008). Effect of some seed pretreatments on emergence of Acacia 
senegal L. World J. Agric. Sci., 4(2):213219.

Saric, M.; Kastrori, R.; Curic, R.; Cupina, T. and Geric, I. (1967). Chlorophyll Determination. Univ. U Noven Sadu Parktikum is Fiziologize Biljaka, Beogard, Haucna, Anjiga, p. 215.

SAS, Institute. (1994). SAS/STAT User's Guides Statistics. Vers. 6.04, $4^{\text {th }}$ Ed., SAS. Institute Inc. Cary, N.C., USA.

Selvaraju, P. and Selvaraj, J.A. (1994). Effect of pre-sowing treatments on germination and vigour of seed in marigold (Tagetes erecta L.). Madras Agric. J., 81(9):469-497.

Sharma, S.; Ranjana, N.; Varghese, B.; Keshavkant, S. and Naithani, S.C. (2008). Effect of hot water treatment on seed germination of some fast growing tropical tree species. J. Tropical Forestry, 24(3/4):49-53.

Singh, A. and Dhillon, G.P.S. (2007). Enhancing germination potential of three leguminous tree species through presowing seed treatments. Indian J. Forestry, 30(2):145-146.

Singh, K.P.; Dhakre, G. and Chauhan, S.V.S. (2005). Effect of mechanical and chemical treatments on seed germination in Pongamia glabra L. Seed Research, 33(2):169-171.
Soliman, A.S. and Abbas, M.S. (2013). Effects of sulfuric acid and hot water pretreatments on seed germination and seedlings growth of Cassia fistula L. American-Eurasian J. Agric. \& Environ. Sci., 13(1):7-15.

Tadros, M.J.; Samarah, N.H. and Alqudah, A.M. (2011). Effect of different presowing seed treatments on the germination of Leucaena leucocephala (Lam.) and Acacia farnesiana (L.). New Forests, 42(3):397-407.

Uniyal, A.K.; Singh, B. and Dhanai, C.S. (2007). Effects of pretreatment on Dalbergia sissoo seed germination. Progressive Research, 2(1/2):144-146.

Wen, H.X.; Wang, Y.; Wu, Y. and Baskin, C.C. (2009). Role of the lens in controlling water uptake in seeds of two Fabaceae species treated with sulfuric acid and hot water. Seed Science Research, 19(2):73-80.

William, M.; Chichlilo, P.; Clifford, P.A. and Reynolds, M. (1965). Official Methods of Analysis of the Association of Official Agriculture Chemists, $10^{\text {th }}$ Ed., Washington D.C. 20044: 52-55.

\footnotetext{
تأثير معاملات ما قبل الزراعة على إنبات بذور ونمو شتثلات شجيرة الكاليندرا

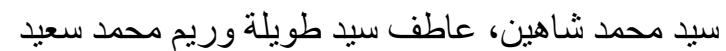

قسم بحوث الحدائق النباتية، معهد بحوث ماثين، البساتين، مركز البحوثةث الزر اعية، الجيزة، مصر.

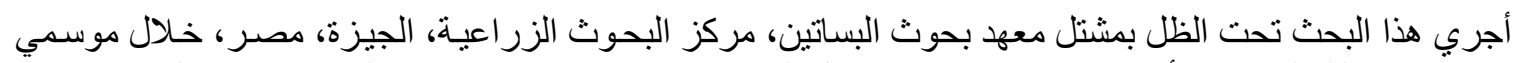

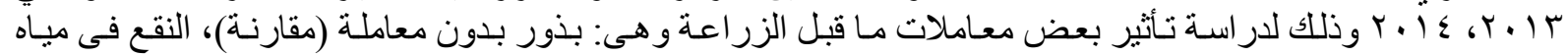

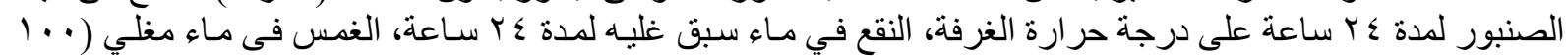

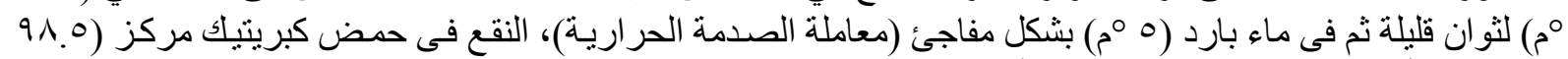

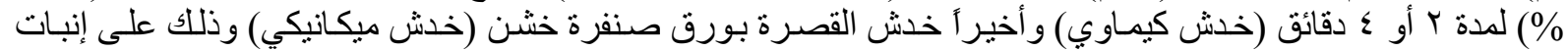
بذور ونمو شتلات شجيرة الكاليندرا (Calliandra haematocephala Hassk.).

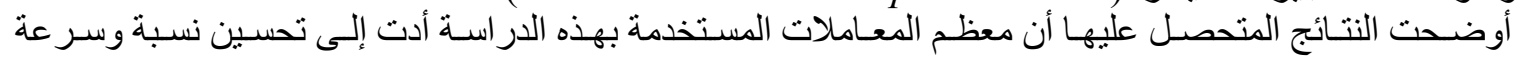

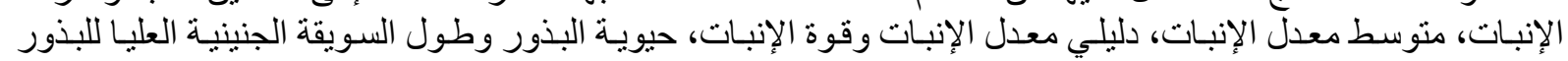




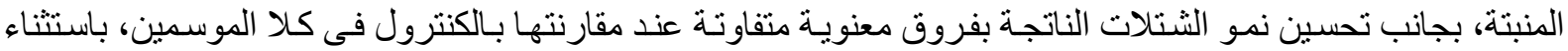

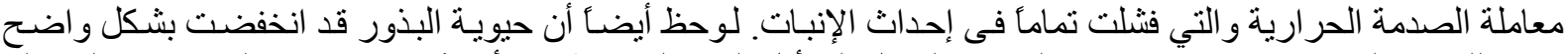

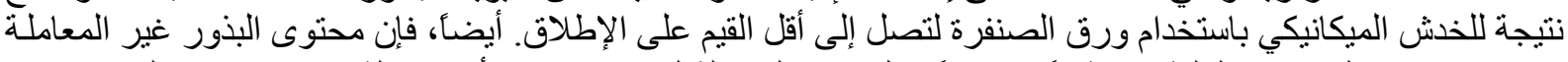

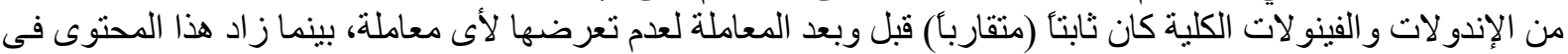

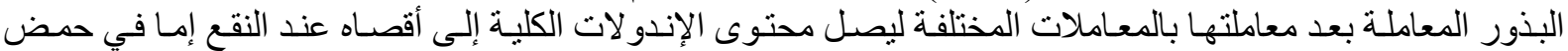

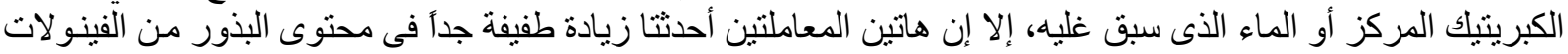

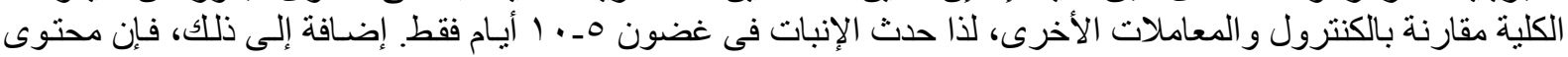

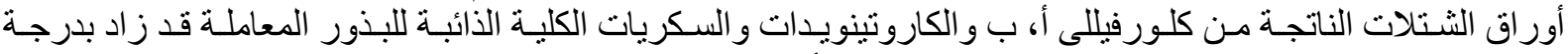

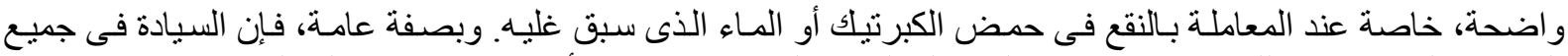

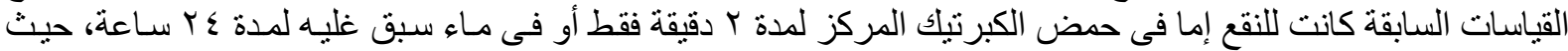

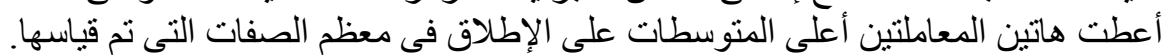

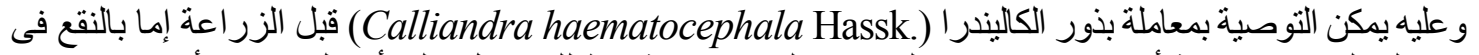

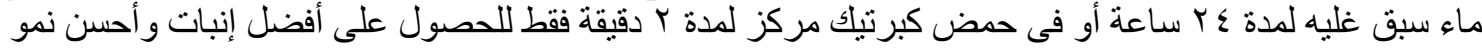


